Document downloaded from:

http://hdl.handle.net/10251/57106

This paper must be cited as:

Peris-Ortiz, M.; Bonet, F.; Rueda Armengot, C. (2011). Vertical integration in production and services: development in transaction cost economics. Service Business. 5(1):87-97. doi:10.1007/s11628-011-0103-0.

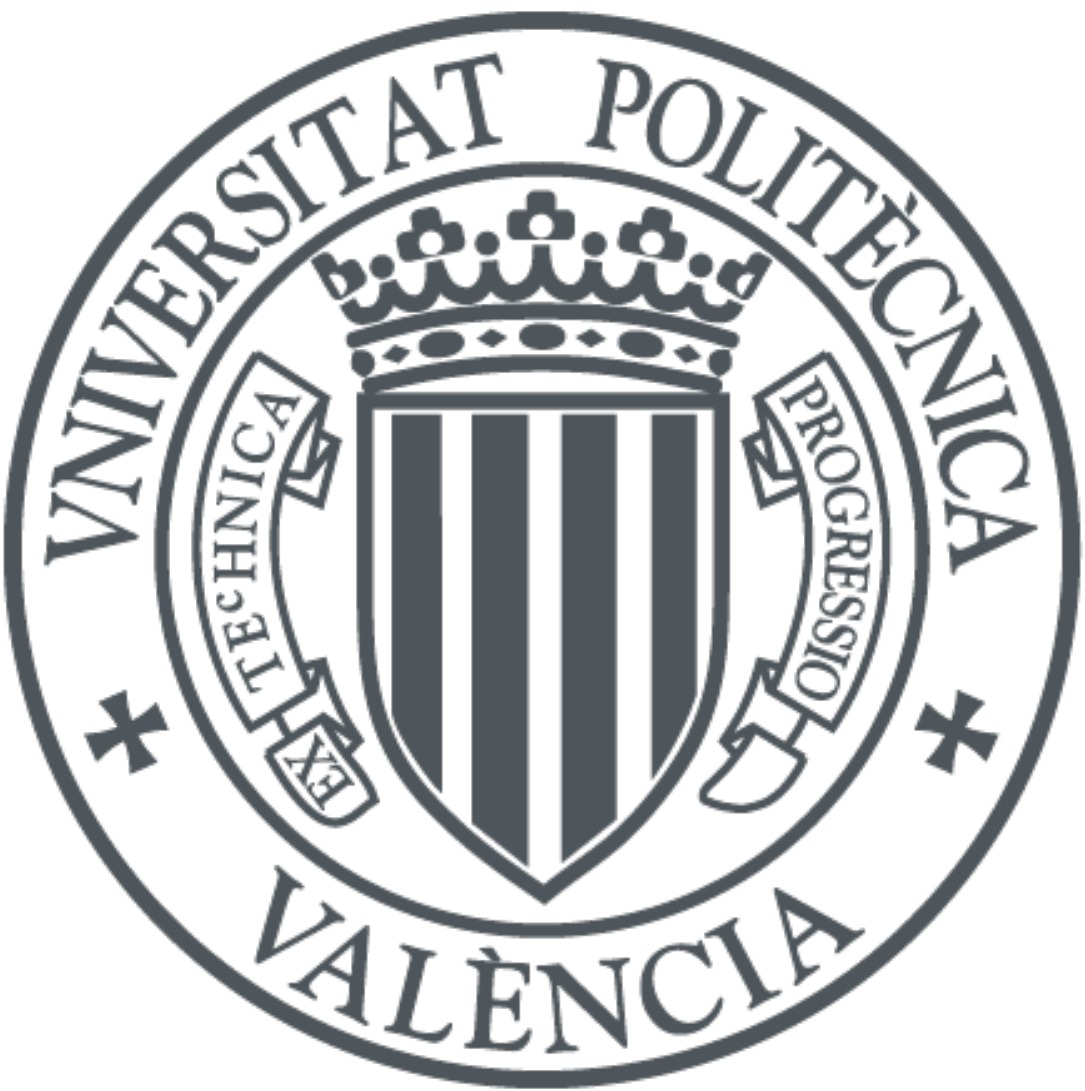

The final publication is available at

http://dx.doi.org/10.1007/s11628-011-0103-0

Copyright Springer Verlag (Germany)

Additional Information 


\title{
VERTICAL INTEGRATION IN PRODUCTION AND SERVICES: DEVELOPMENT IN TRANSACTION COST ECONOMICS
}

Marta Peris-Ortiz • Fernando J. Peris Bonet •

Carlos Rueda-Armengot

\begin{abstract}
In this paper, we firstly establish the core, fundamental concepts of Williamson's TCE, examining the different governance structures or the institutional alternatives that TCE theory proposes. We go on to describe some critical considerations and theoretical proposals that correspond fundamentally to Williamson's heuristic model, the integration of incentives in organizational forms, idiosyncratic demand, and how the concept of transaction is conceived in general
\end{abstract}

\section{Introduction}

The economic theory of transaction costs, as laid down by Williamson, stems from his interest in literature that explains how markets function, the way industry is structured and the various ways in which organizations work (Coase, 1937, 1972; Bain, 1956, 1958; Arrow, 1959, 1973, 1974; Alchian, 1965, 1969; Demsetz, 1967, 1991; Alchian and Demsetz, 1972), considering markets and organizations, or the contractual relations between them, as alternative, institutional structures for obtaining efficiency. In Williamson's modern-day version of transaction cost economics (TCE) $(1975,1979$, 1981, 1985, 1991, 1993, 1999, 2000, 2003, 2005, 2008) nothing can occur without the presence of organizations. They are present in the level of competitiveness of markets (large or small numbers; Williamson, 1975, 1985), in the type of market (Robinson, 1933; Williamson, 1975), and in the choice of institutional alternatives (Williamson, 1985, 1991, 2003).

The market alone is the economic space where different organizations and different agents concur, although the laws of large numbers mean that the market is part of nature itself. As a result, the explanation of the nature of markets (or the ultimate reason for the way they are) arises from the technological and organizational characteristics of the firms that make it up, and the individual (cognitive and moral) characteristics of the agents as members of those organizations or through their actions within the market. The most influential authors for Williamson, with regard to the way he conceives organizations, according to Barnard (1938), are Simon (1947), Chandler 
(1962, 1977) Cyert and March (1963) and Ouchi (1979, 1980). However, Williamson's fundamental concept of idiosyncratic demand, which explains the existence of organizations and some of their most basic characteristics, derives from the application of his concept of specific assets to organizations.

Specific assets are present in two facets in Williamson's TCE: specific investments and idiosyncratic demand. The first concept, which has been described at length by the author $(1975,1985,1991,2003)$; and the second -one of extraordinary potency- has been used without being extensively or sufficiently developed (1981, 1985).

The former case is related to special investments on behalf of a single client or for a small number of clients, whose adaptation to other uses (to other clients in the same sector) implies relevant costs (non-recoverable sank costs). The latter does not deal with costs related to investment in material or tangible costs, but rather to costs that occur when the behaviour of agents (cognitive and moral aspect) do not comply with what has been asked of them (idiosyncratic demand).

These two aspects of the theory, specific investment and idiosyncratic demand, together with the behaviour of agents, make up the cornerstone of TCE in the relations between firms (Williamson, 1975). In the backward relations of the client firm with suppliers, where investments have differing levels of specificity, relations will generally consist of productive activities on the part of supplier firms for their clients; and if the level of specificity is too high, the client will resort to integrating the activity (vertical integration in production; Williamson, 1985: Chapter 4). In terms of the forward relations of the client firms with other firms, in which there are different levels of idiosyncratic demand, the content of relations is generally made up of distribution or retail activities and the sale of products of the client firm by distributor firms or retailers; and if the level of idiosyncratic demand is too high, the client will resort to integrating the activity (vertical integration in services; Williamson, 1981: 1549).

The nature of these two forms of specific assets is completely different. In the first case, integration occurs because one or both of the firms are not willing to take on the risk of the specific assets; risks that have to do with the hold up that can occur for the supplier due to the sank costs of the investment or shortage of supply suffered by the client. However, idiosyncratic demand refers to the risk taken on by the client firm due to possible free rider behaviour on the part of distributors or retailers, in cases where 
these agents do not display the behaviour demanded for maintaining the quality or image of the brand name of the client firm (Williamson, 1985).

In addition, idiosyncratic demand is related to strategic demand, as we can see in the evolution of railroad companies in the US (Chandler, 1977: 134-144 and chap. 5; Williamson, 1985: 277). Difficulties inherent in obtaining partners whose behaviour allows for a common strategy lead to the integration of different firms. Finally, in a more microorganizational approach, nothing that is technically separable would be done jointly in organizations if it were not for the existence of idiosyncratic demand. That is to say, if it were not for the existence of the purpose of coordinating and combining the activity in a common, simultaneous way with the same objectives in mind.

In the following sections, we firstly establish the core, fundamental concepts of Williamson's TCE, examining the different governance structures or the institutional alternatives that TCE theory proposes. We go on to describe some critical considerations and theoretical proposals that correspond fundamentally to Williamson's heuristic model, the integration of incentives in organizational forms, idiosyncratic demand, and how the concept of transaction is conceived in general.

Without the theory laid down by Williamson, none of the additions to the theory we propose here would be possible. However, once the theory exists and becomes the patrimony of the entire scientific community, these additions are an important means of enriching the theory, más allá del uso tradicional de la misma (Li et al., 2009; Un et al., 2009; Palmer et al., 2010) o de otros conceptos próximos a la TCE (Safón, 2009; Warren et al., 2009).

\section{Make or buy decisions in backward relations}

The individual cognitive and moral characteristics in Williamson's TCE correspond, respectively, to the concepts of rationality (intention) and opportunistic search in self interest (or opportunism). These concepts establish a conception of fundamental human behaviour for the theory. In general, if the limits of reason and opportunism are absent, this corresponds to a scenario in which plenitude and human happiness is possible; whilst if the limits of reason exist and there is the opportunistic search for self-interest, this leads to important difficulties for establishing agreements of a social, economic nature and, consequently, produces high transaction costs 
(Williamson, 1985: 65-67) favouring backward or forward integration, or integration of a strategic nature.

Williamson's fundamental contribution in this respect is the existence of market competition amongst many: absence of specific, relevant investment and large numbers. When there is a large amount of supply and great demand in the relationship between suppliers and client firms, competition disciplines behaviour and corrects opportunism, establishing general conditions that the agents must accept. Such a situation enables agreements and reduces contract (or transaction) costs. The integration of activities by client firms in this case will be lower and the structure of the industry will be characterized by the existence of many supplier firms, bringing about greater fragmentation of the industry.

If the opposite occurs, when there is short supply and a lack of demand in the relationship between supplier firms and client firms, weak competition does not correct opportunism, agreements are hindered and contract (or transaction) costs increase. Under such conditions, the integration of activities of client firms will be greater and will lead to more concentrated industries.

The application of these ideas to distributor firms or retailers (the forward way) is not impossible. There may be industrial sectors in which there are many distributor firms or many retail firms that enable the end product or service to reach the consumer, whose characteristics imply a low level of idiosyncratic demand on the part of the firm that obtains them (client firm). This would then imply conditions of competition amongst many, which, as we have mentioned, disciplines behaviour and reduces transaction costs. However, the low level of idiosyncratic demand necessary for this case will only come about with goods or services for which the level of quality or prestige of the brand name are not highly relevant, or when the goods or services in question are not easily exposed to deterioration in the forward way as a result of the inadequate behaviour of agents. If these conditions do not arise, the existence of many distributors or many retailers is insufficient because there is no market that allows for the verification ex ante the intangibles of the intentions or behaviour of distributors and retailers, in a general sense, the backward relation in tangible markets is of a different nature in comparison to the forward relation.

Continuing with the backward case, Williamson's fundamental contribution in this respect is the identification of the economic cause that leads to the existence of 
small numbers: the existence of specific investment (or special investment carried out by suppliers for a reduced number of clients whose alternative uses imply relevant costs). These investments reduce the market to the scope of goods or services obtained via specific assets and, in extreme conditions, lead to a bilateral relation between the client firm and the supplier. Therefore, in the absence of competition as a mechanism that disciplines opportunism, transaction costs increase, making exchange more difficult and motivating the integration of activities within the firm, explaining the concentration of the industry.

This is, a grosso modo, the essential contribution of Williamson to the understanding of markets and the structure of production in industry (in the backward way), in which transactions are the explanatory variable, and the form of governance and industrial structure are the explained variables. If the level of specific investment is low and involves transaction costs that are not relevant, the efficient governance structure for the client firm (in acquiring components or subcontracting activities) will be the instant spot market, supposing -as Williamson's theory does in an explicit or tacit way- that the activities involved are technically inseparable and they have no relevant idiosyncratic demand upon them. This is the case of fragmented industries.

If the level of specific investment is considerable, and involves transaction costs that can be assumed by both sides, the governance structure, in general, will consist of establishing agreements or safeguards via which the client firm will externalize separable activities upon which there is no relevant idiosyncratic demand. Agreements reduce the risk of suppliers (sank costs) and clients (stock shortages) and, depending on the difficulties inherent in the agreements and their costs, industries will become more or less fragmented. Lastly, if the demand for specific investment is very high, and contract costs cannot be taken on by any of the parties involved, the governance structure will consist of internally organizing the activity, though they may be activities in which the firm does not have relevant idiosyncratic demand. This will increase both the size of the firm and the concentration of the industry.

The aspects described above pertaining to Williamson's TCE should be completed by the level of uncertainty existing in the market, whose alterations enable or hinder (make cheaper or more expensive) contracts; and by the condition of recurrence, which corresponds to the number of transactions carried out within the framework of a contract, reducing or increasing the cost of unit exchanges. Thus, in what we refer to as 
backward way relations, the relation of causality proposed by Williamson becomes complete between types of transaction and governance structures, explaining the vertical integration of the firm and the structure of industry (or the institutional structure of production), as Coase (1991) called it.

Therefore, by making a crossover between the implications of behaviour and the level of specific investment, Williamson provides an explanation of the economic conditions that lead to differing levels of negotiation and transaction costs, and to one or other forms of governance structure or institutional framework (spot market, agreements and contracts between firms, and hierarchical organizations). If to this we add the levels of idiosyncratic demand, which are fundamental in Williamson's TCE, we can represent the ideas reflected thus far in figure 1.

In figure 1 , we use the notation $\mathrm{K}=0$ when the level of specific investment is not highly relevant, $\mathrm{K}>0$ when specific investment is relevant but can be taken on by both sides, and $\mathrm{K} \gg 0$ when the importance of specific investment is such that satisfactory guarantees or safeguards between the supplier and client firm cannot be found. With regard to idiosyncratic demand (ID), it is labelled as ID $=0$ when it is not relevant and allows products or services to be obtained via activities organized outside the firm, through the spot market or through agreements between firms; and the notation ID > 0 when it is relevant and implies obtaining products or services directly from within the firm. Finally, we use $S>0$ and $S=0$ to denote the existence or absence of guarantees or safeguards. This allows us to explain branches A, B and C in figure 1.

For $\mathrm{K}=0$ (branch $\mathrm{A}$ of figure 1) the governance structure is the market itself. It represents a situation where there is competition amongst many; a fact that, as we have mentioned, disciplines behaviour, reducing costs and making it desirable for firms to externalize activities. We also assume in this case that ID $=0$. For $\mathrm{K}>0$ (branches $\mathrm{B}$ and $\mathrm{C}$ in figure 1), investment is relevant but can be absorbed by both sides, and can be carried out without any kind of agreement or establishment of guarantees $(S=0)$ with the client firm (branch B), or by establishing a set of guarantees $(S>0)$ with the client firm (branch $\mathrm{C}$, figure 1). We continue with the assumption that ID $=0$ in branches $\mathrm{B}$ and $\mathrm{C}$. The most common solution for establishing guarantees is the realignment of incentives, as some sort of penalty will be incurred if the contract is not completed, a fact that creates a specialized governance structure and introduces trading regularities that support and signal continuity intentions (Williamson, 1985: 34). 
For $\mathrm{K} \gg$, once the level of specific investment cannot be satisfactorily guaranteed by any set of safeguards, the efficient governance structure for organizing the activities of the firm (branch D, figure 1), whatever the value of the idiosyncratic demand (ID $=0$ or ID $>$ o), will be the internalization. Such a situation opens up new internal possibilities, via differing organizational forms that represent variations within the firm's governance structure or institutional form.

\section{Figura 1. Basic contractual map}

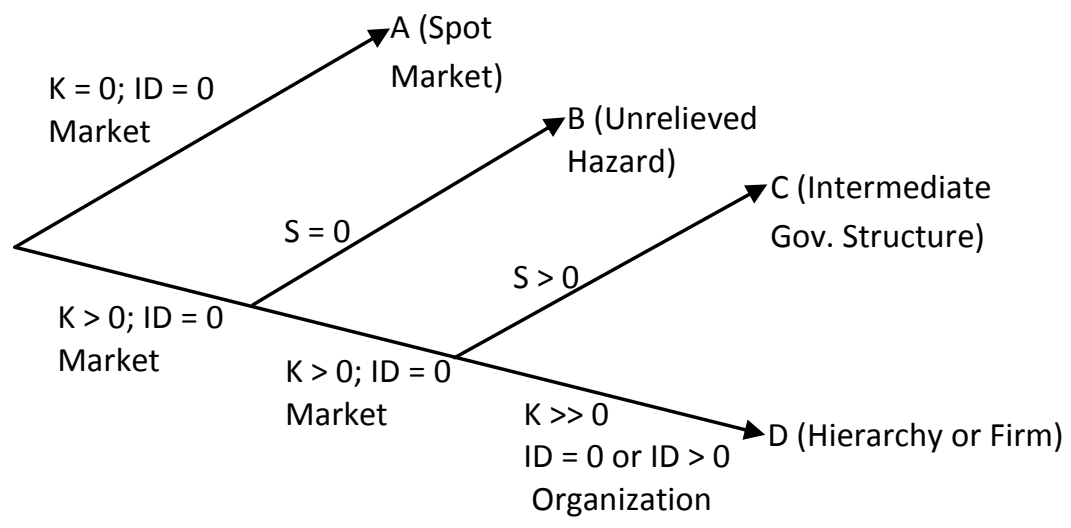

Adapted from Williamson 1985: 33

We go on to analyze Williamson's TCE, developing the governance structure of the firm in greater depth.

\section{Organizational theory, backward and forward relations}

Once we are dealing with the governance structure of the firm, branch D in figure 1 can break off (in figure 2) into D, E and F. Williamson's basic organizational theory can be summarized in what the author calls the hierarchical decomposition principle (1981: 1550), incentive ramifications (1985: 140) and the requirements or idiosyncratic demand of certain organizational units over others (ibid.: 275-277).

With regard to the hierarchical decomposition principle, with a view to providing the solution to a variety of operative and organizational problems, and enabling limited 
rationality to come into play (Simon, 1947, 1973), the total system of decisions needs to be made into relative independent subsystems. In the words of Williamson (1981: 1550), it is necessary to group "the operating parts into separable entities, the interaction within which are strong and between which are weak", whilst distinguishing, in establishing different organizational forms, between "temporal ramifications of a strategic versus operating kind", thus grouping according to the degree of interdependence between tasks; and according to the problems they will have to confront, be they long or short-term. ${ }^{1}$

With regard to the ramification of incentives or the differences between varying types of incentives, Williamson states that markets are strict and unforgiving (highpowered incentives), whilst organizations are compassionate with their members (lowpowered incentives); also highlighting the fact that high-powered incentives do not work well in organizations (1985: 135-140).

High-powered incentives in organizations consist of measuring the performance of different agents according to the profit obtained, which is patently applicable to managers of organizational units whose income and costs can be examined separately. In such a case, the balance sheet is the deciding factor. However, this can have negative consequences for the firm. The balance sheet can improve by avoiding costs in $\mathrm{R}+\mathrm{D}$, reducing maintenance costs for technical equipment or other similar actions. Therefore, it will be necessary to apply low-powered incentives based, above all, on the observation of the actions of agents, which allows for a more complete assessment. The cost of applying these less demanding incentives, as well as those inherent in the observation and description of the work involved, lies in the fact that it allows, to a certain extent, non optimal behaviour. However, (Williamson, 1985: 137), "it is in the mutual interest of firm and worker to safeguard the employment relation against abrupt termination (by either party) wherever labour develops firm specific skills and knowledge during the course of its employment."

Finally, the requirements or idiosyncratic demand of certain organizational units on others, or between the different, technically separable activities within each unit, constitute the very essence of the existence of organizations. The specific or idiosyncratic demands of certain organizations (organizational units or firms) on others, at operative levels (Williamson, 1985: 275) or strategic ones (Ibid.: 277), explain both

\footnotetext{
${ }^{1}$ Simon (1962: 477) is cited by Williamson as a reference for the paragraph in speech marks.
} 
size and organizational form (Ibid.: chap. 11). However, it is important to distinguish between these two cases. (1) When the existence of free rider behaviour or the divergence of legitimate interests do not allow for the satisfaction of idiosyncratic requirements via partnership agreements with other firms, although both parties may be able to assume the requirements of specific investment $\quad(K=0$ or $K>0$ e ID > $)$; which is a question of demands on the behaviour of the partner, not represented in figure 1. (2) And in a situation where $K \gg 0$, which, on its own, explains the internalization of certain activities, the values of idiosyncratic demand (ID $=0$ or ID > 0 ) and internal safeguards $\left(S^{*}\right)$ lead to different organizational structures or to different corporate institutional forms.

By taking a deeper look at idiosyncratic demand, figure 2 represents only case (2) as an extension of figure 1. We thereby reflect Williamson's substantial contribution to organizational theory, and develop it further with ideas that are implicit in the thoughts of this author.

\section{Figure 2. Extended contractual map}

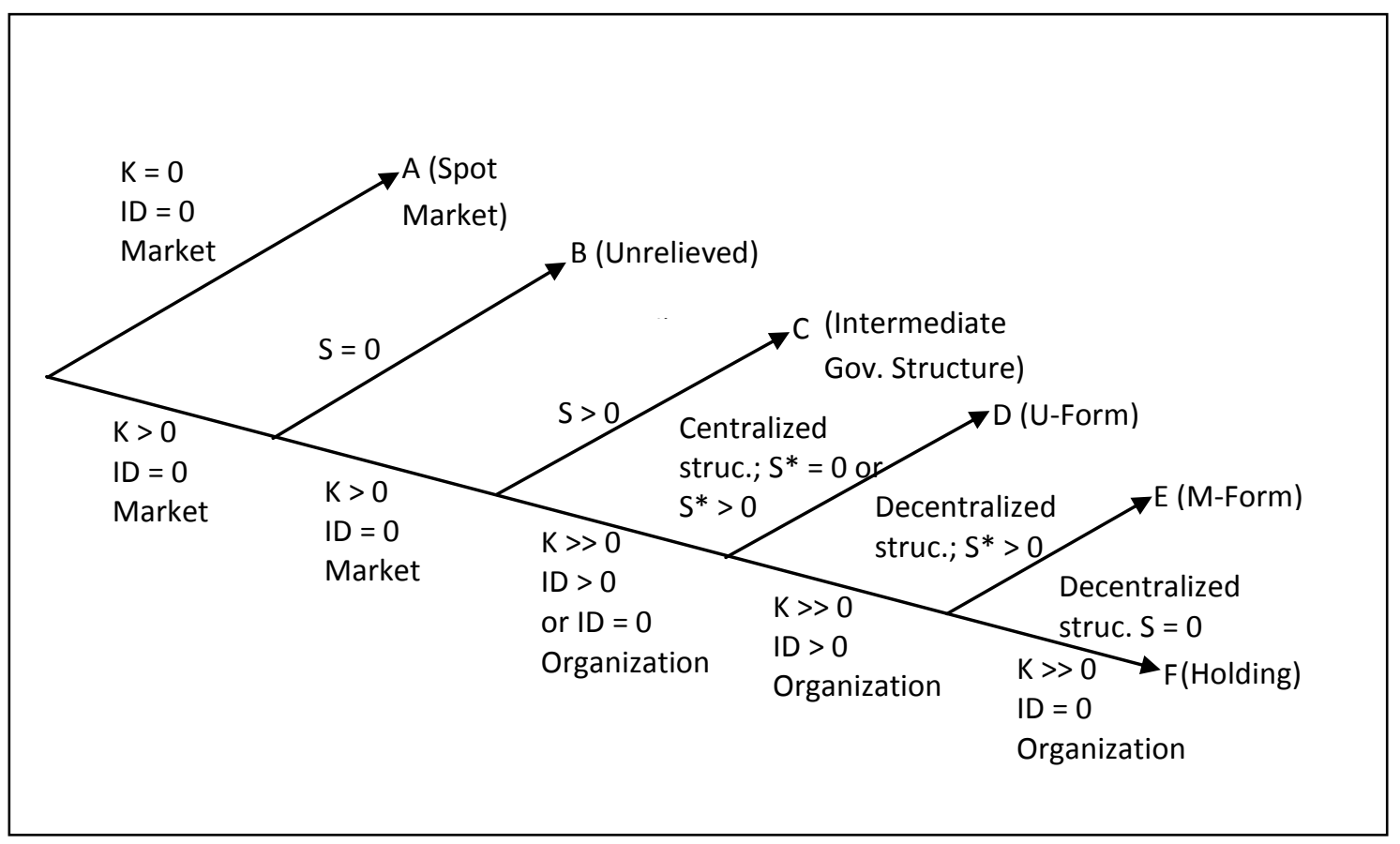

If we describe figure 2, in its organizational branches $\mathrm{D}, \mathrm{E}$ and $\mathrm{F}$, with regard to branch $\mathrm{D}$, we can establish that part of the activities integrated into the firm are due to idiosyncratic demand (ID >0), while other activities will be integrated as a result of $\mathrm{K}$ >> 0 (although in terms of the latter, ID $=0$ is possible). Equally, the centralized structure should be interpreted here as the dependence of all the organizational units on 
the same hierarchical management of the firm (Williamson, 1985; Galbraith, 1993). Finally, $S^{*}$ corresponds to the safeguards or guarantees between the agents that, inside the firm, refer to the relations between the organization's members, apart from hierarchical order, by the greater or lesser levels of socialization and commitment to the objectives of the firm $\left(\mathrm{S}^{*}>0\right.$ or $\left.\mathrm{S}^{*}=0\right)$.

Thus, branch $\mathrm{D}$ in figure 1 , and the U-form type of firm it leads to, has as its essential elements a centralized structure and a level of idiosyncratic demand (ID >0) that explains the (technologically separable) elements that constitute the firm before externalizing or internalizing activities, and the internalized activities as a result of the existence of specific investment with a high level of specificity $(K>0)$. The internalized activities, apart from the core initial activities that make up the firm (ID > 0 ), may be a consequence of $\mathrm{K}>>0$ and ID $=0$, of $\mathrm{K}>>0$ and ID $>0$, or of $\mathrm{K}>0$ and ID $>0$ (this last case, not reflected in figure 2 for reasons of simplicity, occurs when the demand for specificity that forces the firm to internalize is on behaviour and not on the goods that constitute the investment).

With regard to branch E, which corresponds to the M-Form firm, the elements that differentiate this from the U-Form firm are its decentralized structure, based on each division having autonomy for organizing its operations and for certain activities linked to operative development, its relevant idiosyncratic demand (ID >0) between the different divisions that make up the M-Form (this is the fundamental reason for the existence of this type of firm, as each division exhausts the economies of scale and is, in itself, an efficient enterprise ${ }^{2}$ ), and the need for levels of commitment to the firm ( $\mathrm{S}^{*}>$ 0 ), at least on the part of the top management of the divisions, ensure that the content of idiosyncratic demand is complied with. With regard to the fundamental structure of the M-Form, which makes it a superior form of organization for organizing incentives and information processing, (Williamson, 1985: chap. 11), notations ID $=0$ and $\mathrm{S}^{*}=0$ express situations that are not overly relevant here.

Finally, branch $\mathrm{F}$ is a spurious organizational form. We could maintain the notation $\mathrm{K} \gg>0$ for the Holding firm, meaning that in the units of enterprises that make it up, a relevant part of its activities are a result of the existence of highly specific

\footnotetext{
${ }^{2}$ In large divisional, multinational companies this is obvious. The division in Europe of the Ford Motor Company, for example, reaches all the necessary economies of scale, including those of research and design.
} 
investments; but in terms of idiosyncratic demand, there is no demand for common policies or strategies among the different units or "divisions" (ID $=0$ ) nor, consequently, are there requirement or a need for commitment $\left(\mathrm{S}^{*}=0\right)$ among the members of the different organizations (Williamson, 1985; Williamson and Bhargava, 1986).

\section{Final discussion and conclusions}

One of the major facets of Williamson's TCE is that the theory simultaneously explains the organization, markets and the contractual relations between firms, in such a way that each of these alternative governance structures can be understood precisely in accordance with the others. As we mentioned in the first paragraph of this article, nothing occurs in Williamson's theory without the presence of organizations. However, we could equally say that nothing occurs in his theory without the presence of the market. In short, it is these alternative governance structures of economic activity-or the alternative institutional forms- that prevail in TCE, as a conceptual framework that attempts to explain the criteria for choosing the most efficient form of governance.

However, in order to be able to choose, one must know the nature of the alternatives from which to select; and in this sense, what do the market and organizations have in common? What are their basic elements? How do they combine and what are their regularities?

This article has attempted to provide answers to these questions by using, in backward relations, the concepts proposed by Williamson in the same order as suggested by the author, and in forward relations by using the concepts and forms of relation whose development is implicit in TCE. In the first case, a sequence can be established made up of high-powered market incentives as opposed to the low-powered incentives of organizations, and as a result, the desirability of externalizing activities, and as a compensatory force, the disadvantages that can arise for externalization when we have $K>0 o K>>0$. In the second case, first of all, relevant idiosyncratic demand, $(I D>0)$ is essential for the existence of organizations in their initial stages; and secondly, in forward relations, the demand for specific behaviour in distribution or in sales, or in policies and strategies (ID >0), leads to the incorporation into the firm of new activities or new organizational units, whatever the level of the absence of specific investment $(\mathrm{K}>0)$. 
Consequently, relating the explanatory variables of the theory with efficient governance structures or with efficient institutional forms, which constitute the explained variable, we can establish that:

(1) For ID $=0$ (with regard to the additional activities that the firm might incorporate), $\mathrm{K}=0$ indicates the spot market as the efficient governance structure.

(2) For ID $=0$ (with regard to the additional activities that the firm might incorporate). $\mathrm{K}>0$ indicates the market with or without safeguards as the efficient governance structure $(S>0$ or $S=0)$.

(3) For $K \gg 0$ (with regard to the additional activities that the firm might subcontract or organize within the firm), this $\mathrm{K}$ value indicates the organization of those activities within the firm as the efficient governance structure, whatever the value of the idiosyncratic demand (ID $=0$ or ID $>0$ ).

(4) Finally, for ID > 0 (with regard to any type of activity, in backward or forward relations), idiosyncratic demand upon the behaviour of agents, linked to these activities implies that the efficient governance structure is the organization of those activities within the firm, whatever the value of $K(K=0$ or $K>0)$.

Aside from laying down the cornerstones, for TCE, Williamson has also laid down the essential institutions for its future development. In ensuing research, we shall continue to take a deeper look at TCE, both in terms of its theoretical development and in its economic and organizational applications.

\section{References}

Alchian, A. (1965): "The basic of some recent advances in the theory of management of the firm", J. Ind. Econ., 14 (December), 30-41.

Alchian, A. (1969): "Corporate management and property rights", in G. H. Manne ed., Economic Policy and Regulation of Corporate Securities, Washington D. C.: American Enterprise Institute of Public Policy Research.

Alchian, A. y Demsetz, H. (1972): "Production, information cost, and economic organization", Am. Econ. Rev., 62 (December), 777-795.

Arrow, K. J. (1959): "Toward a theory of price adjustment", in Moses Abramovitz et al., eds., The allocation of resources, Stanford, California: Stanford University Press, 41-51. 
Arrow, K. J. (1973): Information and economic behaviour, Stockholm: Federation of Swedish Industries.

Arrow, K. J. (1974): The limits of organizations, New York: W. W. Norton.

Bain, J. (1956): Barriers to new competition, Cambridge, Mass.: Harvard University Press.

Bain, J. (1958): Industrial organization, 2d ed. New York: John Wiley \& Sons.

Barnard, C. I. (1938): The Functions of the Executive, Cambridge, Mass.: Cambridge University Press.

Chandler, A. C. Jr. (1962): Strategy and Structure, Cambridge Mass.: MIT Press.

Chandler, A. C. Jr. (1977): The visible Hand. Cambridge, Mass.: Harvard University Press.

Coase, R. H. (1937): “The Nature of the Firm”, Economica, 4 (November), 386-405.

Coase, R. H. (1972): “Industrial Organization: A Proposal for Research", en Victor, R. Fuchs (ed.), Policy Issues and Research Opportunities in Industrial Organization, National Bureau of Economics Research, New York, pp. 59-73.

Coase, R. H. (1991): “The Institutional Structure of Production", Prize Lecture to the Memory of Alfred Nobel, December 9, 1991, in http://www.nobel.se/economics/ laureates/ 1991/coase-lecture.html

Cyert, R. M. and March, J. G. (1963): A behavioural theory of the firm, Englewood Cliffs, N. J.: Prentice-Hall.

Demsetz, H. (1967): “Toward a theory of property rights”, A Econ Rev, 57, May, 347359.

Demsetz, H. (1991): “The Theory of the Firm Revisited", en Williamson, O. y Winter, S. (Eds.), The Nature of the Firm: Origins, Evolution, and Development, New York: Oxford University Press, 159-178.

Galbraith, J. R. (1993) "The value-adding corporation: matching structure with strategy", in J. R. Galbraith, E. E. Lawler III and Associates (eds.), Organizing for the Future, San Francisco: Jossey-Bass Publishers, 15-42.

Li, J-M., Yang, J-S. and Wu, H. H. (2009): "Analysis of competence differences among frontline employees from various service typologies", The Service Industries Journal, 29, 12, 1763-1778.

Ouchi, W. G. (1979): "A Conceptual Framework for the Design of Organizational Control Mechanism", Manage Sci, Vol. 25, 9, September, 833-848. 
Ouchi, W. G. (1980): "Markets, Bureaucracies, and Clans", Admin. Sci. Quart., Vol. 25, March, 120-142.

Palmer, M., Owens, M. and De Kervenoael, R. (2010): "Paths of the least resistance: understanding how motives form in international retail joint venturing", The Service Industries Journal, 30, 6, 965-989.

Robinson, Joan (1933): The economics of imperfect competition, London: Macmillan.

Safón, V. (2009): "The moderating effect of the technological level of industry on the relationship between innovation and corporate reputation", International Entrepreneurship and Management Journal, 5, 4, 515-526.

Simon, H. A. (1947): Administrative Behavior, New York: Macmillan.

Simon, H. A. (1962): "The architecture of complexity", Proceedings of the American Philosophical Society, 106 (December), 467-482.

Simon, H. A. (1973): “Applying information technology to organization design", Public Admin. Rev., 33 (May-June), 268-278.

Un, C. A., Romero-Martínez, A. M. and Montoro-Sánchez, A. (2009): "Determinants of R\&D collaboration of service firms", Service Business, 3, 373-394.

Warren, L., Patton, D. and Bream, D. (2009): "Knowledge adquisition processes during the incubation of new high technology firms", International Entrepreneurship and Management Journal, 5, 4, 481-495.

Williamson, O. E. (1975): Markets and Hierarchies: Analysis and Antitrust Implication, New York: Free Press.

Williamson, O. E. (1979): "Transaction-Cost Economics: the governance of contractual relations", J. Law Econ., 22 (October), 3-61.

Williamson, O. E (1981): "The Modern Corporation: Origins, Evolution, Attributes", J. Econ. Lit., 19 (December), 1537-1568.

Williamson, O. E. (1985): The Economic Institutions of Capitalism, Free Press, Nueva York.

Williamson, O. E. and Bhargava, W. H. (1986): "Assesing and Classifying the Internal Structure and Control Apparatus of the Modern Corporation", in Oliver E. Williamson: Economic Organization. Firms, Markets and Policy Control, pp. 54-80. Great Britain, Brighton: Wheatsheaf Books.

Williamson, O. E. (1991): "Comparative economic organization: The analysis of discrete structural alternatives”, Admin. Sci. Quart., 36 (June), 269-296. 
Williamson, O. E. (1993): "Calculativeness Trust and Economic Organization", J. Law Econ., 36. In Williamson O.E (1996): The Mechanisms of Governance, Oxford University Press, 250-278.

Williamson, O. E. (1999): "Strategy research: governance and competence perspectives", Strateg. Manage. J., 20, 1087-1108.

Williamson, O. E. (2000): “The New Institutional Economics: Taking Stock, Looking Ahead", J. Econ. Lit., 38, 595-613.

Williamson, O. E. (2003): "Examining economic organization through the lens of contract", Ind. Corp. Change, 12, 4, 917-938.

Williamson, O. E. (2005): "Transaction cost economics and business administration", Scand. J. Manag., 21, 19-40.

Williamson, O. E. (2008): "Outsourcing: transaction cost economics and supply chain management”, J. Supply Chain Manage.44, 2, April, 5-16. 